\title{
Analysis of the Influence of Environmental Performance, Leverage, and Size of Companies on Csr Disclosures with Profitability as Moderating
}

\author{
Nur Asih Triatmaja ${ }^{1}$, Unna Ria Safitri ${ }^{2}$, Alean Kistiani H.S ${ }^{3}$, Dasmadi ${ }^{4}$, Listyowati Puji.R ${ }^{5}$ \\ Fakultas Ekonomi Universitas Boyolali ${ }^{1,2,3,4,5}$ \\ \{nurasihtriatmaja@gmail.com¹,unnaria68@gmail.com², aleankistiani@gmail.com³, \\ dasmadi82@gmail.com ${ }^{4}$, listyowatipuji120@gmail.com $\left.{ }^{5}\right\}$
}

\begin{abstract}
This study aims to determine, analyze and test the effect of environmental performance, leverage, and company size on CSR disclosure with profitability as a moderating variable listed on the Indonesia Stock Exchange. The population of this study is the consumer goods sector companies 2015-2018. Of the 63 listed companies, only 20 companies met the sample criteria using purposive sampling as the sampling method. The data analysis technique used multiple linear regression. Based on the results of the analysis, it can be seen that environmental performance has an effect on CSR disclosure. Leverage has an effect on CSR disclosure. Company size has no effect on CSR disclosure. Profitability variable is a moderating variable that is unable to moderate the relationship between environmental performance and CSR disclosure. Profitability is a moderatingvariable that is unable to moderate the relationship between leverage and CSR disclosure. Profitability is a moderating variable that is unable to moderate the relationship between company size and CSR disclosure.
\end{abstract}

Keywords: Environmental Performance; Leverage; Company Size; CSR; Profitability

\section{Introduction}

All types of business activities, especially those engaged in the utilization of resources, either directly or indirectly, certainly have an impact on the surrounding environment, such as problems with environmental pollution, labor, and also problems related to the products produced (Nur and Priantinah, 2012). Therefore it takes a commitment from the company to convince and gain the trust of stakeholders, especially the community that the company has fulfilled this responsibility, namely through activities that are able to improve the welfare of the community itself. The trust gained from the community greatly affects the company's ability to maintain its business sustainability (going concern) (Rahajeng, 2010). Each company will strive to attract public sympathy and trust through positive activities that side with the interests of the community. These activities are known as corporate social responsibility.

Corporate social responsibility (CSR) is a mechanism for companies to voluntarily integrate environmental and social concerns into their operations and interactions with 
stakeholders, which goes beyond the organization's legal responsibilities (Darwin, $200 \$$ ). Companies that carry out CSR will have a good image in the eyes of the community. A good corporate image is expected to provide stakeholders with good news or signals in decision making that can benefit the company. This is in accordance with Angela's opinion, 2015, namely by implementing CSR. There are several factors that influence CSR, including Environmental Performance, Leverage, Company Size and Profitability.

Environmental performance is often associated with the disclosure of corporate social responsibility (CSR) disclosure carried out by the company. Companies with good environmental performance will also get good assessments from stakeholders. Therefore, companies will tend to have a high level of CSR disclosure in the hope that it can be taken into consideration by investors in making investment decisions that do not only look at the company's performance from a financial perspective, but also take into account the environmental performance.

Lucyanda and Siagian (2012), as well as Oktariani and Mimba (2014) conducted research on the factors that influence social responsibility disclosure in companies in Indonesia and the results show that there is a significant positive effect of environmental performance on social responsibility disclosure. A different result is shown by Anggraini (2006), namely that environmental performance has no effect on disclosure of corporate environmental and social responsibility

Another factor that can affect the level of CSR disclosure is leverage. Leverage reflects how much the company depends on creditors in terms of financing the company's assets. Companies with a high degree of leverage will reduce their social responsibility disclosures so that they do not become the spotlight of debtholders (Belkaoui and Karpik, 1989). Several studies that have been conducted to examine the effect of leverage on CSR disclosure include research conducted by Shubiri et al. (2012) which shows a significant negative effect between leverage and CSR disclosure. This is supported by research conducted by Oktariani and Mimba (2014) who found that leverage has a negative effect on a company's CSR disclosure. However, these results are not in line with the results of research conducted by Untari (2010), Lucyanda and Siagian (2012), and Check et al. (2013) who found that there was no significant effect between leverage and CSR disclosure. Based on the above background and the results of previous studies, the authors conducted research on "Environmental Performance Analysis, Leverage, Company Size on CSR with Profitability as a Moderation Variable". The novelty of this study is to use profitability as a mediating variable. Problem Formulation Based on the above background, the formulation of the problem in this study is as follows:

a. Does environmental performance affect CSR in consumer goods manufacturing companies listed on the IDX for the 2015-2018 period?

b. Does leverage affect CSR in consumer goods manufacturing companies listed on the IDX for the 2015-2018 period?

c. Does company size affect CSR in consumer goods manufacturing companies listed on the IDX for the 2015-2018 period?

d. Does profitability moderate the relationship between environmental performance and CSR in consumer goods manufacturing companies listed on the IDX for the 2015-2018 period?

e. Does profitability moderate the relationship between leverage and CSR in consumer goods manufacturing companies listed on the IDX for the 2015-2018 period?

f. Does profitability moderate the relationship between company size and CSR in consumer goods manufacturing companies listed on the IDX for the 2015-2018 period? 


\section{Theory Basis}

\subsection{Stakeholder Theory}

The term stakeholder was first introduced by the Stamford Research Institute (SRI), from this thinking more or less leads to the existence of an organization that is strongly influenced by the support of groups who see nature as something that must be conquered (Kuhlman, 2010). Stakeholder theory states that a company is not an entity that only operates for its own interests, but that the company is also required to be able to provide benefits for its stakeholders. Thus, the existence of a company is strongly influenced by the support provided by the company's stakeholders (Saputro 2013).

\subsection{Corporate Social Responsibility a Definition and Concept of Corporate Social Responsibility (CSR)}

\section{a) The Implementation of Corporate Social and Environmental Responsibility}

The implementation of corporate social and environmental responsibility is not limited to responsibility that is reactive in nature, namely the responsibility that is carried out because the company has had a negative impact on society and the environment. Companies also need to design programs and efforts to prevent potential negative impacts or risks of the company's economic activities on society and the environment, which are company stakeholders (Lako, 2010). According to Moon (2004) in Putra (2010) CSR is a difficult concept to define. The concept of CSR has increased in recent years. CSR is a concept that has attracted worldwide attention and has also received attention in the global economy. However, this CSR concept still not uniform with varying views about their potential uses and applicability Lako (2010) states that CSR is a necessity that must be done. CSR must be made as an essential need that is internalized in management systems and business practices and organizational culture. The need to make CSR a true need is increasingly felt. This is because first, this action will bring abundant blessings for the company, and secondly because the business world is and will continue to face external pressure to care about CSR. This pressure comes from market players, particularly investors and creditors, who are increasingly concerned about and sensitive to social and environmental issues (CSR) because they are linked to risks and prospects for investment and credit. In addition, international institutions such as the United Nations, World Bank, IMF, European Union and others, are increasingly emphasizing the importance of internalizing CSR in corporate business policies and practices. The last pressure is from the government, which is likely to increase in line with the spread of social and environmental degradation in the country. Therefore, business actors must immediately reform their business paradigm, which has tended to be conservative and pragmatic, towards a more CSR-friendly direction

\section{b) Disclosure of Corporate Social Responsibility}

According to Rahmawati (2012) explains that disclosure means not hiding or covering something up. Since 23 September 2007, disclosure of corporate social responsibility or what is known as corporate social responsibility disclosure has become mandatory through the Limited Liability Company Law Number 40 of 2007, especially for companies that live from natural resource extraction. Article 74 of the Law regulates the obligation to disclose corporate 
social and environmental responsibility, so that there is no longer any mention of voluntary corporate social responsibility disclosure, but disclosure that is obligatory. Meanwhile, the development of corporate social responsibility.abroad, it is very popular even in some countries, corporate social responsibility is also used as an indicator of a company's performance appraisal by including information on corporate social responsibility in the financial statements of the company concerned. According to Deegan (2002) (in Purwanto, 2011) there are several reasons why companies make social and environmental disclosures, namely:

1. The desire to comply with the requirements contained in the law.

2. Consideration of economic rationality. By doing social and environmental disclosure the company will get business benefits because the company is doing the right thing.

3. Desire for accountability or accountability to report. Managers have the belief that everyone has an inescapable right to obtain satisfactory information and managers do not care about the costs involved in presenting that information.

4. Willingness to comply with loan requirements. The risk management policies of lending institutions tend to require their borrowers to provide various information regarding their performance and social and environmental policies on a periodic basis.

5. To fulfill or adjust to the expectations / desires of the community.

6. As a consequence of threats to community legitimacy.

7. To manage certain stakeholder groups that have a big influence on the company.

8. To attract investors.

9. To comply with certain industry requirements (code of product).

10. To win certain reporting awards. This can make the company's reputation good in the eyes of stakeholders

\section{c) CSR Measurement}

The CSR disclosure standards used in this study refer to the GRI (Global Reporting Initiative) Standards. In the GRI Standards, performance indicators are divided into 3 categories, namely: Economic, environmental, and social. The social category consists of 4 sub-categories, namely: labor and employment practices, human rights, society, and product responsibility. Then, the 3 categories are further divided into 149 disclosure items. The approach to calculating the index of social responsibility disclosure in this study uses dummy variables, namely by giving the number 1 for items disclosed by the company, and the number 0 for items that are not disclosed. After that the scores of each item are added up to obtain the total overall score for each company.

\subsection{Definition and Measurement of Environmental Performance}

\section{a) Definition of Environmental Performance}

The Indonesian National Standard Agency (2005) states that various kinds of organizations are increasingly concerned about the achievement and demonstration of good environmental performance through controlling environmental impacts associated with the activities, products and services of the organization concerned, consistent with their environmental policies and objectives. This is carried out in the context of tighter laws and regulations, the development of economic policies and other instruments that promote environmental 
protection. In addition, it is also to increase the awareness of parties with an interest in the environment.

Environmental performance is the company's performance in creating a good environment (Suratno et al., 2006). Companies pay attention to the environment as a form of corporate responsibility and concern for the environment. Environmental performance itself can be done by applying environmental accounting. Fitriyani (2012) states that Environmental accounting is the disclosure and integration of the impact of environmental issues on a company's traditional accounting system. Environmental accounting not only calculates the economic costs and benefits of a company, but also considers environmental costs that are negative economic externalities or costs that arise outside the market.

Related to the theory of legitimacy, good environmental performance must be owned by the company as an effort to create an organization that is environmentally friendly or cares about the surrounding environment, so that it can increase the company's legitimacy in the eyes of the community. International standard organizations reveal that in achieving good environmental performance, a system must be implemented. good environmental management too. A reliable, effective, and documented environmental management system will encourage increased company performance by controlling all aspects that have a negative impact on the environment.

\section{b) Environmental Performance Measurement}

Several ways of measuring environmental performance have been carried out by previous researchers. Performance measurement usually used in measuring environmental performance is based on ISO 14001 achievement by the company. ISO 14001 was introduced in the 1990s, which was a development in the management or quality management aspect. The international standards organization on its official website www.iso.org explains that ISO 14001 is an international standard on the application of an environmental management system issued by the International Standards for Organization (ISO). This standard combines and balances business interests with the environment. So that the performance improvement efforts made by the company will be adjusted to the company's resources, both natural, human, technical and financial.

An environmental management system (EMS) based on ISO 14001 is part of the overall management system which includes organizational structure, planning activities, responsibilities, practices, procedures, processes and resources for developing, implementing, achieving, reviewing and maintaining policies. environment. The application of ISO 14001 is a systems approach, so applying these standards means improving the system. ISO 14001 is not the domination of large companies alone, the ISO 14001 standard is very flexible, can be applied in various types and scales of activity. System implementation can be initiated and carried out by existing resources by providing trainings. The main purpose of implementing the system is not solely to get certified, but is to be able to improve the system and get benefits both financially and for the environment itself.

Certification for ISO 14001 means that the company's environmental management system is accessed, assessed or evaluated and the results have met the requirements in accordance with ISO 14001 EMS. There are 3 basic components in ISO 14001, namely a written environmental program, education and training, and knowledge of local and national laws and regulations.

The International Standard Organization states that ISO 14001 is the most recognized standard in the world related to environmental management system frameworks. Based on the 
description above, it can be concluded that ISO 14001 helps organizations to better manage the impact of their activities on the environment. One of the objectives of ISO 14001 is to encourage efforts and take an approach to the management of the environment and natural resources and the quality of their management is uniform in the global scope. ISO 14001 certificate can be used as evidence of the eligibility of an organization, business, and manufacturing facilities in demonstrating responsibility to the environment. This certification is very important for a business or entity to remain competitive in national and international markets in this era of environmental awareness. ISO 14001 itself has been adopted by Indonesia as a national standard, namely SNI 19-14001: 2005. This proves that the ISO 14001 international standard can be applied in Indonesia.

\subsection{Definition and Concept of Leverage}

\section{a) Definition of Leverage}

Various definitions regarding leverage have been expressed by many experts. Leverage can be said as a tool to measure how much a company depends on creditors in financing the company's assets (Karina, 2013). Companies that have a high level of leverage mean that they are very dependent on external loans to finance their assets, while companies that have a lower level of leverage are more likely to finance their assets with their own capital. The level of corporate leverage reflects the company's financial risk (Purnasiswa, 2011). Adawiyah (2013) states that the leverage ratio is related to funding decisions where companies prefer debt financing to their own capital. This ratio also shows how much the company is financed by outsiders or creditorsIn accordance with the theory of stakeholders, companies with high levels of leverage will consider the use of their business results and assets (assets) to pay their liabilities to debtholders rather than to finance their social responsibility activities and their disclosures, so that the delivery of information needed by stakeholders is not optimal.

\section{b) Leverage Measurement}

According to Kasmir (2018) explains that the leverage ratio is a ratio used to measure the extent to which the company's assets are financed with debt, meaning how much debt is used by the company to finance its business activities when compared to using its own capital so that the comparison of these two ratios can be seen clearly, we can use the leverage ratio. The advantages of using this ratio according to Kasmir (2018) are:

1. Can assess the ability of the company's position to obligations to other parties.

2. Assessing the company's ability to meet fixed obligations.

3. Knowing the balance between the value of assets, especially fixed assets and capital.

4. In order to make decisions on the use of sources of funds in the future.

According to Kasmir (2018), it shows that the leverage ratio is a ratio used to measure the extent to which the company's assets are financed with debt, which means how much debt the company bears compared to its assets, in a broad sense it is said that the leverage ratio is used to measure the company's ability to pay. all obligations, both short and long term, if the company is dissolved (liquidated). The use of leverage ratios for companies provides many benefits, both low and high ratios.

\subsection{Company Size}


Company size refers to the size of the company, with indicators such as total assets and total sales. This is because the company's wealth and resources are reflected in how big the sales are, this can also save good prospects in the future as a positive signal by investors so that the value (of shares) of the company is positive. Brigham and Houston (2005) define firm size as the average of total net sales for the year to several years. Company size is a characteristic of a company in relation to its corporate structure. Company size can be measured from the total assets owned by the company.

\subsection{Profitability}

Profitability can be defined as the company's ability to generate profits. Company profitability is a factor that makes management free and flexible to disclose social responsibility to shareholders (Darwis, 2009). Profitability is the net result of a number of company policies and decisions. Profitability ratio measures how much the company's ability to generate profits. Profitability is determined by financial ratios as one of the analyzes in analyzing the financial condition, results of operations and level of profitability of a company.

\subsection{Hypothesis}

a. H1: Environmental performance has an effect on CSR

b. H2: leverage affects CSR

c. H3: Company size has no effect on CSR

d. H4: Does profitability do not moderate the relationship between environmental performance and CSR

e. H5: Profitability does not moderate the relationship between leverage and CSR

f. H6: profitability does not moderate the relationship between company size and CSR

\section{Research Methodology}

\subsection{Research Objects}

The object of this research is documentary data in the form of annual financial reports of manufacturing companies in the consumption industry sector listed on the IDX, and other similar CSR disclosure reports during the 2015-2018 period.

\subsection{Types and Sources of Data}

This research was conducted through several processes, namely collecting, compiling, and analyzing data and interpreting the data. Secondary data obtained through the official website of the Indonesia Stock Exchange: http: //www.idx.co.id. This research uses data from audited financial reports on consumer goods industry sector companies for the period 2015-2018.

\subsection{Population and Sample}

This study used secondary data obtained from IDX (Indonesian Stock Exchanges) 20152018. This study uses 1 time period with the total data of companies in the consumer goods 
industry sector. The sample selected using purposive sampling method with the following criteria:
a. Listed and active consumer goods industry sector companies from 2015 to 2018.
b. The company discloses its CSR report in its annual report for the 2015-2018 accounting period which can be accessed through the official website of the Indonesia Stock Exchange (www.idx.co.id).
c. Publish financial reports on the IDX for the period 2015 to 2018.
d. Companies that experienced profits in the period 2015 to 2018.

\subsection{Data Collection Techniques}

The data used in this study is secondary data in the form of annual reports of manufacturing companies listed on the Indonesia Stock Exchange. The secondary data was obtained from the official website of the Indonesia Stock Exchange (www.idx.co.id) and matched with data obtained directly from the Indonesia Stock Exchange office. In addition, information regarding the GRI Version 4.0 index regarding CSR disclosure is obtained from the official website www.globalreporting.org. Meanwhile, information about ISO 14001 regarding environmental management is obtained directly from the ISO website, namely www.iso.org. The method used is the documentary method.

\subsection{Data Analysis Techniques}

The data analysis technique used the classical assumption test, normality test, multicollinearity test, heteroscedasticity test.

\subsection{Hypothesis Testing}

Hypothesis testing in this study uses Multiple Linear Regression, Correlation Coefficient $(\mathrm{R}), \mathrm{t}$ test, coefficient of determination and $\mathrm{F}$ test.

\section{Results and Discussion}

\subsection{Data Collection}

The research object used in this research is manufacturing companies listed on the Indonesia Stock Exchange. The data used in this study comes from the 2015 to 2019 financial reports and annual reports. Which can be accessed directly through the Indonesia Stock Exchange website (www.idx.com) or the websites of each sample company. The sample selection in this study was determined using the purposive sampling method with several provisions described in table VI.1 so that 26 samples were obtained as follows:

Table 1. So that 26 samples were obtained

\begin{tabular}{llc}
\hline \multicolumn{1}{c}{ Information } & amount \\
\hline 1 & $\begin{array}{l}\text { Consumer Goods Sector Companies listed on the IDX from } \\
2015 \text { to 2019 } \\
\text { Companies that do not disclose their Corporate Social }\end{array}$ & \\
2 & $\begin{array}{l}\text { Responsibility (CSR) reports in their annual reports for the } \\
\text { period 2015 to 2019 }\end{array}$
\end{tabular}




\begin{tabular}{llc}
\hline & \multicolumn{1}{c}{ Information } & amount \\
\hline 3 & financial reports on the IDX that do not publish financial & $(12)$ \\
4. & Comorts for the period 2015 to 2018 & $(6)$ \\
Number of companies & 20 \\
\hline
\end{tabular}

Based on the research sampling that has been presented in the previous chapter, 20 samples of companies with predetermined criteria were obtained. After obtaining a list of companies that are sampled the next step is collecting data on environmental performance, leverage, company size, disclosure of Corporate Social Responsibility (CSR) and Profitability. Then then perform data analysis in accordance with the previous chapter.

\subsection{Classic Assumption Test}

The regression model equation in research can be used to estimate with significance and representativeness if the regression model does not deviate from the classical basic assumptions of regression in the form of: normality, multicollinearity, heteroscedasticity, and autocoleration.

\section{a) Normality Test}

The normality test is used to test whether the regression model, confounding or residual variables have a normal distribution. As it is known that the $\mathrm{t}$ and $\mathrm{F}$ tests assume that the residual value follows a normal distribution. If this assumption is prohibited, the statistical test becomes invalid for a small sample size. There are two ways to detect whether the residuals are normally distributed or not, namely by graphical analysis or statistical tests with the onesample Kolmogorov-Smirnov test (Ghozali, 2011: 160-165). In this study, the normality test was carried out by the Kolmogorov-Smirnov statistical test. In the One Sample Kolmogorov Smirnov Test, the residuals have Asymp. Sig (2-tailed) below the significant level of 0.05 (probability $<0.05$ ) this means that the variable has an abnormal distribution and vice versa. In the regression normality assumption, the normality test is carried out on the residuals of the regression (complete calculations can be seen in the appendix).

Table 2. Data Normality Test Results

\begin{tabular}{cc}
\hline \multicolumn{2}{c}{ Unstandardized residual } \\
\hline Kolmogorov-Smirnov & 0,77 \\
Value Asymp. Sig & 0,200 \\
\hline Source: Secondary Data Processed, 2021, Appendix 4.
\end{tabular}

Based on these results using the Kolmogorov-Smirnov $\mathrm{Z}$ test showed a value of 0.77 and an Asymp value. Size of .200. The significance value for the regression model is greater than 0.05 . This means that the regression for this research model is normally distributed and all data have a normal data distribution.

\section{b) Multicollinearity Test}

Multicolonierity test is used to test whether the regression model found a correlation between independent variables (independent). A good regression model should not have a 
correlation between the independent variables. If the independent variables are correlated, these variables are not orthogonal. Orthogonal variables are independent variables where the correlation value between independent variables is equal to zero (Ghozali, 2011: 105-106). Multicollinearity, can be seen from the tolerance value and the opposite of variance inflation factor (VIF). The cut-off value commonly used to indicate multicollinearity is a tolerance value $>0.10$ or equal to the VIF value $<10$. From the calculation results, the following results are obtained:

Table 3. Multicollinearity Test Results 1

\begin{tabular}{cccc}
\hline Variable & Tolerance & VIF & Information \\
\hline $\mathrm{K}$ &, 629 & 1,589 & There is no Multicollinearity problem \\
$\mathrm{L}$ &, 628 & 1,593 & There is no Multicollinearity problem \\
$\mathrm{S}$ &, 954 & 1,048 & There is no Multicollinearity problem \\
$\mathrm{P}$ &, 516 & 1,938 & There is no Multicollinearity problem \\
\hline \multicolumn{4}{c}{ Source: Processed data, 2021, attachment 4 }
\end{tabular}

The multicollinearity calculation results show that all independent variables have a tolerance value of more than $0.1(10 \%)$, this means that there is no correlation between the independent variables whose value is more than $95 \%$. The results of the calculation also show that all independent variables have a VIF of less than $10(<10)$. So it can be concluded that there are no symptoms of multicollinearity in the regression model used. Or this means that there is no correlation between the independent variables.

\section{c) Heteroscedasticity Test}

Heteroscedasticity test is used to test whether in the regression model there is an inequality of variance from the residuals of one observation to another. if the residual variance from one observation to another is constant, it is called homoscedasticity and if it is different it is called heteroscedasticity. A good regression model is one that is homoscedastic or means that there is no heteroscedasticity. Most of the cross section data contain heteroscedasticity situations because this data collects data that represents various sizes both small, medium and large (Ghozali, 2011: 139). Heteroscedasticity test analysis is used with the Glejser technique, namely by performing regression analysis using the residual value as the dependent variable obtained from ordinary regression analysis, then then comparing the significance value with the $\mathrm{p}$ value according to the criteria in the previous chapter.

From the calculation results as in table V.4 below, it shows that there is no heteroscedasticity disorder that occurs in the estimation process of the estimator model parameters, where according to the initial criteria that there is no heteroscedasticity, if the probability value is $>0.05$. Because, all significance values are greater than 0.05 , so there is no heteroscedasticity problem in this study. Based on the classical assumption test (normality, autocoleration, multicollinearity, heteroscedasticity), it is found that the model used does not deviate from the classical assumptions, this means that the regression model in this study can be used as a basis for analysis.

Table 4. Heteroscedasticity Test Results

\begin{tabular}{ccc}
\hline Variabel & $\begin{array}{c}\text { TOTAL } \\
\text { p-value }\end{array}$ & Description \\
\hline $\mathrm{K}$ &, 617 & Heteroscedasticity free \\
$\mathrm{L}$ &, 405 & Heteroscedasticity free \\
\hline
\end{tabular}




\begin{tabular}{ccc}
\hline Variabel & $\begin{array}{c}\text { TOTAL } \\
\text { p-value }\end{array}$ & Description \\
\hline S &, 595 & Heteroscedasticity free \\
K.P &, 280 & Heteroscedasticity free \\
L.P &, 389 & Heteroscedasticity free \\
S.P &, 882 & Heteroscedasticity free \\
\hline \multicolumn{2}{c}{ Source: Processed data, 2021, attachment 4 }
\end{tabular}

\subsection{Hypothesis Testing}

\section{a) Multiple Regression Analysis}

In this study using a statistical model, namely multiple regression analysis. This test is performed using Moderated Regression Analysis (MRA). Moderated Regression Analysis (MRA) is a special application of multiple linear regression where the equation contains elements of interaction (Ghozali, 2009). By using the help of IBM SPSS in statistical calculations. Based on table V.5, the regression equation is obtained as follows:

$\mathrm{NP}=, 316+, 058 \mathrm{k}+-, 025 \mathrm{~L}+, 002 \mathrm{~S}+-, 001 \mathrm{~K} \cdot \mathrm{P}, 003 \mathrm{~L} . \mathrm{P}+-1,11 \mathrm{~S} . \mathrm{P}+\mathrm{e}$

Table 5. Multiple Regression Test

\begin{tabular}{crrr}
\hline \multirow{2}{*}{ Variable } & \multicolumn{3}{c}{ Equation } \\
\cline { 2 - 4 } & coefficient & t count & Sig \\
\hline (Constant) &, 316 & 13,164 &, 000 \\
K &, 058 & 2,875 &, 005 \\
L &,- 025 &,- 563 &, 575 \\
S &, 002 & 1,942 &, 056 \\
K.P &,- 001 & $-1,474$ &, 145 \\
L.P &, 003 & 1,266 &, 210 \\
S.P & $-1,11$ &,- 535 &, 595 \\
\hline Source: Processed Secondary Data, 2021 & Annex 4
\end{tabular}

Based on the multiple regression above, it can be interpreted as follows:

1. From the table above shows that if environmental performance (K), Leverage (L), Company Size (S), Environmental performance (K) X Profitability (P), Leverage (L) X Profitability (P) and Company Size $(\mathrm{S}) \times$ Profitability $(\mathrm{P})$ is zero $(0)$, so the corporate social responsibility (CSR) variable is a constant number of, 316.

2. This shows that the environmental performance variable $(\mathrm{K})$ has a coefficient value of, 058 , tcount of 2.875 and a significance level of 0.005 . A positive sign means that if the environmental performance variable $(\mathrm{K})$ has increased by one unit, assuming the independent variable is constant, the corporate social responsibility (CSR) variable has increased by 0.058 or $58 \%$.

3. variable Leverage (L) has a coefficient value of -0.025 thitung is 1.942 and a significance level of 0.056 . The negative sign means that if the Leverage (L) variable has decreased by one unit, assuming the independent variable is constant, the corporate social responsibility (CSR) variable has decreased by 0.025 or $25 \%$.

4. The firm size variable (S) has a coefficient value of .002 , tcount of 1.942 and a significance level of 0.056. A positive sign means that if the variable Company Size (S) has increased by one unit, assuming the independent variable is constant, the corporate social responsibility (CSR) variable has an increase of 0.002 or $2 \%$. 
5. In this study, using the Profitability variable as a moderating variable, while the interaction between environmental performance $(\mathrm{K})$ and profitability has a negative coefficient of -001 count of -1.474 and a significance level of 0.145 . This shows that the interaction between environmental performance $(\mathrm{K})$ and profitability will decrease and increase corporate social responsibility (CSR). The negative sign means that the environmental performance variable $(\mathrm{K})$ weakens the influence of the relationship between environmental performance $(\mathrm{K})$ on corporate social responsibility (CSR) 0.001 or $11 \%$.

6. The Leverage (L) variable has a positive coefficient of .003 tcount of 1.266 and a significance level of 0,210 . This means that if Leverage (L) increases with profitability it will increase corporate social responsibility (CSR). The positive sign means that profitability strengthens the influence of the relationship between Leverage (L) on corporate social responsibility (CSR) by 0.003 or $0.3 \%$.

7. The company size variable (S) has a negative coefficient of -1.11 , with a count of-, 535 and a significance level of 0.595 . This means that if the size of the company (S) decreases with profitability, it will decrease to corporate social responsibility (CSR). The negative sign means that profitability weakens the influence of the relationship between Company Size (S) on corporate social responsibility (CSR) by 1.11 or $111 \%$.

\section{b) Test of Significance of Individual Parameters ( $t$ test)}

Basically, the $t$ test serves to measure how far the influence of one independent variable individually in explaining the dependent variations. The results of the $t$ test can be seen in the following table:

Table 6. Results of the Significance of Individual Parameters ( $t$ test)

\begin{tabular}{|c|c|c|c|c|c|c|}
\hline Variable & $P$-value & $t$ count & $\begin{array}{c}\text { Sig } \\
\text { value }\end{array}$ & $\begin{array}{c}\text { Conclusion Description } \\
\text { Type of Moderation }\end{array}$ & $\begin{array}{l}\text { Description } \\
\text { Moderation }\end{array}$ & $\begin{array}{c}\text { Type of } \\
\text { Moderation }\end{array}$ \\
\hline $\mathrm{K}$ & $\mathrm{P}<0,05$ & 13,164 &, 000 & Signifikan & H1received & \\
\hline $\mathrm{L}$ & $\mathrm{P}<0,05$ & 2,875 &, 005 & Significant & $\mathrm{H} 2$ received & \\
\hline $\mathrm{S}$ & $\mathrm{P}<0,05$ &,- 563 &, 575 & Not significant & & \\
\hline K.P & $\mathrm{P}<0,05$ & 1,942 &, 056 & Not significant & H3not accepted & $\begin{array}{l}\text { Predictor } \\
\text { Moderating }\end{array}$ \\
\hline L.P & $\mathrm{P}<0,05$ & $-1,474$ &, 145 & Not significant & H4 not accepted & $\begin{array}{l}\text { Predictor } \\
\text { Moderating }\end{array}$ \\
\hline S.P & $\mathrm{P}<0,05$ & 1,266 &, 210 & Not significant & H5not accepted & $\begin{array}{c}\text { Holnologiser } \\
\text { Moderating }\end{array}$ \\
\hline
\end{tabular}

Source: Processed data, 2021, attachment 4

significance $0.05(\mathrm{P}<5)$. From the results of the $t$ test in the table above shows that:

1. Hypothesis 1 of this study hypothesizes the influence of environmental performance (K) on corporate social responsibility (CSR). The results of testing the hypothesis 1 show that $t$ count is 13.164 with a significance of, $000 \quad(P<0.05)$. This means that environmental performance (K) affects corporate social responsibility (CSR). Thus Hypothesis 1 is accepted.

2. Hypothesis 2 of this study hypothesizes the influence of Leverage (L) on corporate social responsibility (CSR). The results of testing hypothesis 2 show that $t$ count is 2.875 with a significance of $.005(\mathrm{P}<0.05)$. This means that Leverage $(\mathrm{L})$ has an influence on corporate social responsibility (CSR). Thus Hypothesis 2 is accepted. 
3. Hypothesis 3 of this study hypothesizes the influence of Company Size (S) on corporate social responsibility (CSR). The results of testing the hypothesis 3 show that $t$ is equal to -, 563 with a significance of, 575 ( $\mathrm{P}>0.05)$. This means that Company Size (S) has no influence on corporate social responsibility (CSR). Thus, Hypothesis 3 is rejected.

4. Hypothesis 4 of this study hypothesizes the influence of profitability in moderating environmental performance (K) on corporate social responsibility (CSR). The results of testing the hypothesis 4 indicate that the $t$ value is 1.942 and the significance value of K.P is 0.056 . This means that profitability does not moderate the effect of environmental performance $(\mathrm{K})$ on corporate social responsibility (CSR). This relationship is included in the Predictor Moderating type of moderation, because ( $\beta 1$ is significant, $\beta 4$ Non significant). Thus Hypothesis 4 is rejected. e. Hypothesis 5 of this study hypothesizes the effect of profitability in moderating Leverage (L) on corporate social responsibility (CSR). The results of testing hypothesis 5 show t count of -1.474 with a significance of $.145(\mathrm{P}>0.05)$. This means that Profitability does not moderate the influence of Leverage (L) corporate social responsibility (CSR). This relationship is included in the Predictor Moderating type of moderation, because ( $\beta 2$ is significant, $\beta 5$ is non-significant). Thus, Hypothesis 5 is rejected.

5. Hypothesis 6 of this study hypothesizes the effect of profitability in moderating Company Size (S) on corporate social responsibility (CSR). The results of testing hypothesis 5 show $t$ count of 1.266 with a significance of, $210(\mathrm{P}>0.05)$. This means that Profitability does not moderate the influence between Company Size (S) corporate social responsibility (CSR). This relationship is included in the Predictor Moderating type of moderation, because ( $\beta 3$ is significant, $\beta 6$ is non-significant). Thus, Hypothesis 6 is rejected.

\section{c) Simultaneous Significance Test (Test F)}

This test is used to determine whether the independent variables simultaneously or jointly affect the dependent variable significantly. The test results can be seen in table VI.9

Table 7. Statistical Test Results F

\begin{tabular}{ccccc}
\hline Variable & Criteria & F Value & Sig Value & Conclusion \\
\hline K,L,S,K.P,L.P,S.P & $\mathrm{P}<0,05$ & 3,399 &, $005^{\mathrm{b}}$ & H0 Received \\
\hline \multicolumn{5}{c}{ Source: Processed data, 2018, attachment 4}
\end{tabular}

The regression results in the table above show that $\mathrm{F}$ is 2.76 with a significant number of 0.005 . The significant value is less than 0.05 , so it can be concluded that this research model is fit, in other words it shows that all independent variables, namely environmental performance, leverage and company size, and their interactions have a simultaneous effect on corporate social responsibility (CSR). So that the regression model can be used in this study.

\section{d) Test the coefficient of determination $\mathrm{R2}$}

The coefficient of determination measures how far the model's ability to explain the dependent variable. The value of the coefficient of determination is between 0 and 1 . The small adjusted R2 value means that the ability of the independent variable to explain the dependent variable is very limited, and vice versa (Ghozali, 2011). The test results can be seen in the following table: 
Table 8. Determination Coefficient Test Results

\begin{tabular}{ccc}
\hline Variabel & Adjusted R Square \\
\hline Equation & K,L,S,K.P,L.P,S.P & 0,154 \\
\hline \multicolumn{2}{c}{ Source: Processed data, 2018, attachment 4 }
\end{tabular}

The calculation results obtained the coefficient of determination (Adjusted R2) is 0.416 This shows that the environmental performance variable (K), Leverage (L), Company Size (S) corporate social responsibility (CSR), and profitability and their interactions are able to explain the variation of the independent variable, namely the value the company is $15.4 \%$ while the remaining $84.6 \%$ is explained by factors or other variables outside the model.

\section{Conclusion}

a. Environmental performance affects the disclosure of Corporate Social Responsibility (CSR) in consumer goods sector companies listed on the IDX from 2015 to 2018

b. Leverage affects the disclosure of Corporate Social Responsibility (CSR) in consumer goods sector companies listed on the IDX from 2015 to 2018.

c. Company Size has no effect on disclosure of Corporate Social Responsibility (CSR) in consumer goods sector companies listed on the IDX from 2015 to 2018.

d. Profitability does not moderate the relationship between environmental performance and affects the disclosure of Corporate Social Responsibility (CSR) in consumer goods sector companies listed on the IDX from 2015 to 2018.

e. Leverage does not moderate the relationship between environmental performance and affects the disclosure of Corporate Social Responsibility (CSR) in consumer goods sector companies listed on the IDX from 2015 to 2018.

f. Company Size does not moderate the relationship between environmental performance and affects the disclosure of Corporate Social Responsibility (CSR) in consumer goods sector companies listed on the IDX from 2015 to 2018.

\section{Referensi}

[1] Arthana, R. 2012. Pengaruh Karakteristik Perusahaan Terhadap Pengungkapan CSR Pada Perusahaan Yang Terdaftar di Indek Bursa Saham.Jurnal Mahasiswa, Fakultas Ekonomi dan Bisnis Universitas Brawijaya, Malang. Badjuri, A. 2011. Faktor-Faktor Fundamental, Mekanisme Coorporate Governance, Pengungkapan Corporate Social Responsibility Perusahaan Manufaktur dan Sumber Daya Alam Indonesia. Jurnal Dinamika Keuangan dan Perbankan, 3(1): 38-54

[2] Cahyono, B. 2010.Pengaruh Corporate Social Responsibility Terhadap Kinerja Perusahaan Dengan Kepemilikan Asing Sebagai Variabel Moderating (Studi Empiris Pada Perusahaan Manufaktur Yang Terdaftar di Bursa efek indonesia). Skripsi. Universitas Diponegoro, Semarang. Chuzairi, A . 2013. Faktor-Faktor yang Mempengaruhi Pengungkapan Corporate Social Responsibility Pada Perusahaan Yang Terdaftar di BEI. Jurnal.umrah.ac.id: 1-15.

[3] Ikhsan, A. K. 2014. Pengaruh Ukuran perusahaan, Leverage, Likuiditas dan Profitabilitas Terhadap Luas Pengungkapan Sosial dalam Laporan Tahunan Perusahaan . Artikel Ilmiah Mahaisiswa, Fakultas Ekonomi Universitas Jember 
[4] Suhaenah. 2013. Analisis Pengaruh Ukuran Perusahaan, Profitabilitas, dan Leverageterhadap Pengungkapan Tanggung Jawab Sosial Perusahaan. Jurnal Jurusan Akuntansi, FE Gunadarma, Jakarta

[5] Pebriana, K. U. S. dan I. M. Sukartha. 2011. Pengaruh Profitabilitas, Leverage, Umur perusahaan, Komposisi Dewan Direksi, dan Kepemilikan Institusional pada Pengungkapan Corporate Social Responsibility di Bursa Efek Indonesia. Artikel. Fakultas Ekonomi Udayana Bali.

[6] Kartika, Amaryllia Sari dan Etna Nur Afri Yuyettu. (2020). "Pengaruh Kinerja Lingkungan, Dewan Komisaris, Leverage dan Political Visibility Terhadap Pengungkapan Corporate Social Responsibility di Indonesia". Diponegoro Journal of Accounting, Volume 10 No. 9 April 2020

[7] Lisa, S.L., Paramita, R.W.D., danTaufiq, M. (2018). "PengaruhSize, ProfitabilitasdanLeverageTerhadapCorporate Social Responsibility (CSR) Disclosurepada Perusahaan IndustriBarangKonsumsi yang Terdaftar di BEI Tahun 2013-2015". JurnalRisetAkuntansi. Volume 1, Nomor 1. (152-164).

[8] Munsaidah, Siti; Rita AndinidanAgusSupriyanto. (2016). "AnalisisPengaruhFirm Size, Age, Profitabilitas, Leverage, danGrowth Perusahaan TerhadapCorporate Social Esponsibility (CSR) Pada Perusahaan Property dan Real Estate Yang Terdaftar di Bursa Efek Indonesia PadaTahun 2010-2014". Journal of Accounting, Volume 2 No. 2 Maret 2016.

[9] Nayahita, Maulidiya. (2018). "AnalisisPengaruhUkuran Perusahaan, Umur Perusahaan, Profitabilitas, LeveragedanPertumbuhan Perusahaan terhadap CSR (StudiEmpirisPada Perusahaan Yang TerdaftarPadaIndexs LQ-45 Indonesia Tahun 20122016)".Skripsi.SarjanaEkonomiAkuntansiUniversitas Islam Indonesia Yogyakarta (tidakdipublikasikan).

[10] Nurjanah, N. (2015). "KinerjaLingkungan, Leverage, ProfildanPertumbuhan Perusahaan; PengaruhnyaTerhadap CSR Disclosure".Skripsi.SarjanaEkonomiJurusanAkuntansiFakultasEkonomiUniversitasNe geri Semarang (tidakdipublikasikan).

[11] Nurtantiono, Andri. (2020). "AnalisisRegresiKasusdanAnalisisdengan SPSS". Surakarta: STIES Press.

[12] Pradnyani, I., danSisdyani, E. (2015). "PengaruhUkuran Perusahaan, Profitabilitas, Leverage, danUkuranDewanKomisarisPadaPengungkapanTanggungJawabSosial Perusahaan". EJurnalAkuntansi, 11(2), 384-397.

[13] Wilangga, Darma I. (2018). "PengaruhProfitabilitas, Ukuran Perusahaan danLeverageTerhadapPengungkapan CSR".Skripsi.SarjanaEkonomiAkuntansiUniversitas Pembangunan Nasional Veteran Jakarta (tidakdipublikasikan).

[14] http://www.iso.org, diaksespadaSenin, 23-03-2021.

[15] http://www.idx.com, diaksespadaSenin, 23-03-2021. 